\title{
Geological Studies to Support the Tourism Site: A Case Study in the Rafflesia Trail, Near Kampung Jedip, Lojing Highlands, Kelantan, Malaysia
}

\author{
Dony Adriansyah Nazaruddin 1*, Nur Syazwani Md. Fadilah', Zurfarahin Zulkarnain1, \\ Sharifah Aisyah Syed Omar², Mohamad Khidzir Mohd Ibrahim ${ }^{3}$ \\ ${ }^{1}$ Geoscience Programme, Faculty of Earth Sciences, Universiti Malaysia Kelantan, UMK Jeli Campus, Jeli, \\ Malaysia \\ ${ }^{2}$ Natural Resources Programme, Faculty of Earth Sciences, Universiti Malaysia Kelantan, UMK Jeli Campus, \\ Jeli, Malaysia \\ ${ }^{3}$ Laboratory of Geology and Soils Science, Faculty of Earth Sciences, Universiti Malaysia Kelantan, UMK Jeli \\ Campus, Jeli, Kelantan, Malaysia \\ Email: ${ }^{*}$ dony@umk.edu.my
}

Received 13 April 2014; revised 8 May 2014; accepted 2 June 2014

Copyright (C) 2014 by authors and Scientific Research Publishing Inc.

This work is licensed under the Creative Commons Attribution International License (CC BY).

http://creativecommons.org/licenses/by/4.0/

(c) (i) Open Access

\section{Abstract}

Some geological studies were performed in the Rafflesia Trail, near Kampung Jedip, in Lojing Highlands, Kelantan. This area is famous for its Rafflesia and has become one of the tourism attractions in Kelantan. However, the recent development of agricultural activities has significant effects on the area. The objective of these studies is to give substantial geological information including geomorphology, lithology, structural features, geohazard potentials, and water quality analysis in the study area. Desk study was conducted by reviewing some literatures related to the topic and the study area. Field work was organized during a scientific expedition in January 2014, to collect data, samples, and photographs. Geomorphologically, the study area is a mountainous area which mostly consists of mountain ridges and mountain valleys. Some fluvial features occur in the study area, such as waterfalls, cascades, rapids, runs, pools, potholes, lateral bars, and point bars. This area is composed of granitic rocks, mostly granite porphyry, and covered by superficial deposits of Quaternary age. The geological structure that is commonly found in the study area is joints, where they divide the rock body into large, roughly angular blocks, which is called as brecciation. The potential geohazard in the study area is landslides, where some of them are composed of soil only and others are mixtures of rock and soil. The water quality analysis has managed to

"Corresponding author.

How to cite this paper: Nazaruddin, D.A., Fadilah, N.S.Md., Zulkarnain, Z., Omar, S.A.S. and Ibrahim, M.K.M. (2014) Geological Studies to Support the Tourism Site: A Case Study in the Rafflesia Trail, Near Kampung Jedip, Lojing Highlands, Kelantan, Malaysia. International Journal of Geosciences, 5, 835-851. http://dx.doi.org/10.4236/ijg.2014.58074 
identify that the stream water in this area generally has the quality of Class III (according to INWQS for Malaysia). These studies recommend that this area should be supported as a sustainable tourism site in Lojing Highlands.

\section{Keywords}

Geological Studies, Sustainable Tourism Site, The Rafflesia Trail, Lojing Highlands, Kelantan

\section{Introduction}

Some geological studies were carried out in the Rafflesia trail and its vicinity, near the settlement of aboriginal people (orang asli) of Temiar ethnic in Kampung Jedip, Lojing Highlands, in the state of Kelantan Darul Naim. This study area is located nearby Cameroon Highlands, a famous tourism destination in the neighbouring state of Pahang. Lojing highlands is one of the forest reserve areas in Kelantan and so far well-known as the home for Rafflesia kerri [1] [2], one of the biggest flowers in the world and the largest species in Peninsular Malaysia. The Rafflesia has become the icon and the main tourism attraction of the highlands. However, the development of agricultural activities has prompted the deforestation in the highlands. As the result, soil erosions, landslides, and other environmental impacts occur extensively in many parts of the highlands.

The present research includes studies on geomorphology, lithology, structural features, geohazard potentials, and water quality analysis of the study area. These studies aim to document the geological resources and potential hazards in the study area, and thus, to support the conservation of the area for sustainable development.

\section{Study Area}

Lojing Highlands is located at the foot of the Main Range (also called the Titiwangsa Range), and adjacent to Cameroon Highlands, Pahang. Lojing is covered with highland tropical rainforest which is rich of flora, fauna, and local communities who live harmoniously with the nature. So, beside Rafflesia, Lojing has more to offer, either biotic or abiotic components and all these will attract scientists and tourists from both domestic and international.

Lojing is located in the south-western corner of Kelantan state with an area size of $1817 \mathrm{sq} \mathrm{km}$. It was officially launched as a sub-district (jajahan kecil) of Kelantan on 5th August 2010 by the Sultan of Kelantan. The Lojing sub-district only forms $22.42 \%$ from the district of Gua Musang with the altitude of $610-1500 \mathrm{~m}$ above sea level. Temperature of the highlands ranges from $18^{\circ} \mathrm{C}-25^{\circ} \mathrm{C}$. It has 3 main areas i.e. Betis Area, Hau Area and Sigar Area. Of the 5613 people recorded as residents here, 4,113 of them are the indigenous race, Temiars. The name "Lojing" was believed by the Temiars that it has been long used before 1900 and it came from the name of the head of a Temiar family, called "Ajing”, the first pioneer at Sungai Belatop. The area was named after him, which then became Lojing [3]. From the interview with some Temiars in the study area during our expedition, they also confirmed and agreed with the aforementioned story.

The studies were focused in the Rafflesia trail along Sungai (River) Denkong, near Kampung Jedip, Lojing Highlands (Figure 1). This study area is just near the settlement for the aboriginal people of Temiar community and is located within the Sungai Beruk Reserve Forest. The study area is close to the Kelantan-Perak border in the west, and Kelantan-Pahang border in the south. To get to the study area, the excellent road network i.e. the Gua Musang-Lojing-Cameroon Highlands Highway is provided to link Lojing with other areas. It is around 15 $\mathrm{km}$ from Cameroon Highlands or about $80 \mathrm{~km}$ from Gua Musang town. Based on our observation during the expedition, up to 30 tourists visit the site daily, mainly for observing the Rafflesia. There are some life stages of Rafflesia that we can observe in the area, starting by the buddings until the decay (Figure 2). Most of the tourists stay in the Cameroon Highlands because of its more complete facilities and development.

\section{Materials and Methods}

Materials of the research include map, photographs and literatures related to the study area and some geological studies, such as geomorphology, lithology, structural features, geohazard potentials as well as water quality 

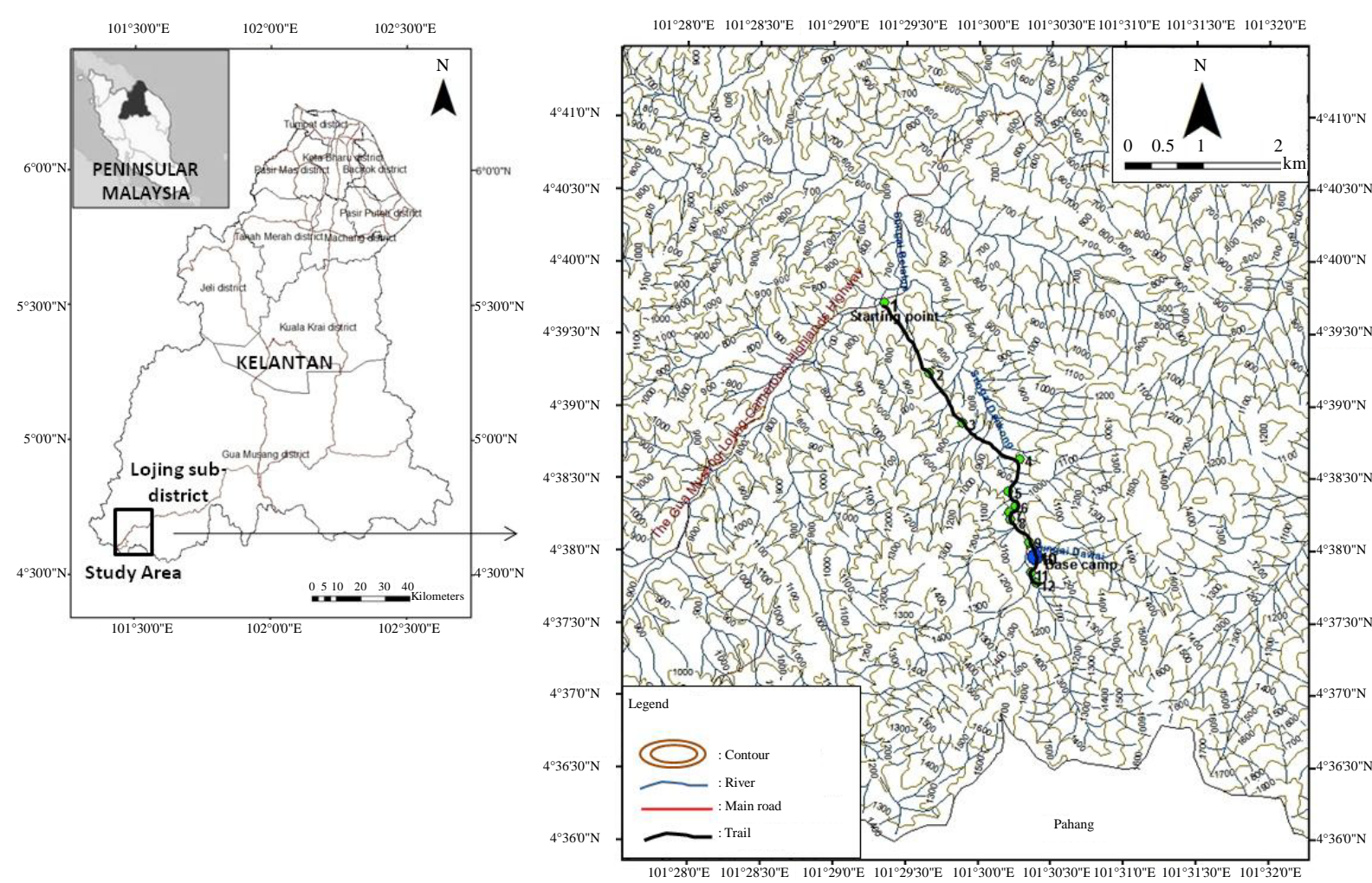

Figure 1. Location map and base map of the study area.
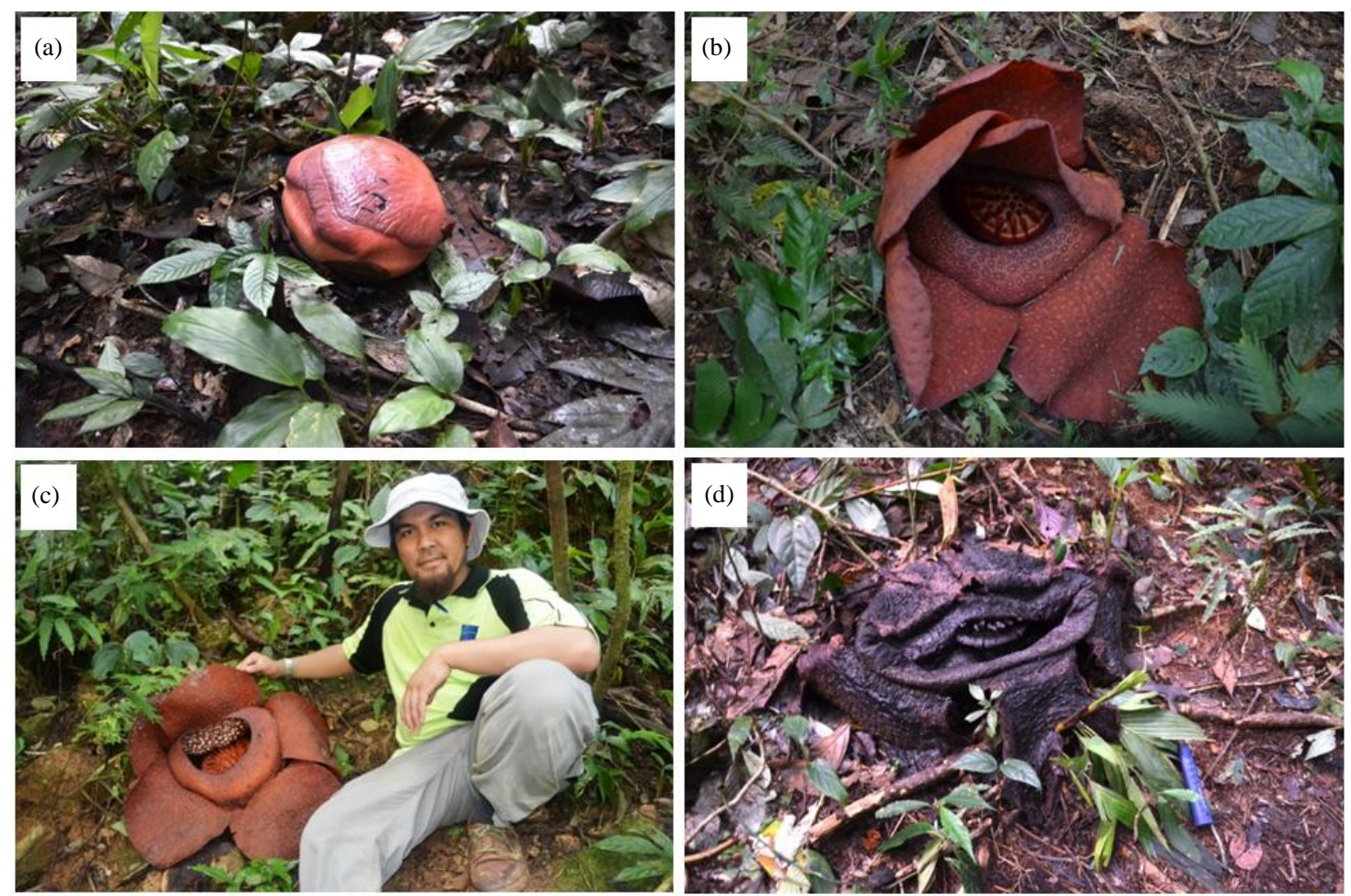

Figure 2. Rafflesia kerri, the icon and the main tourism attraction of Lojing highlands. Some Rafflesia life stages can be observed in the study area such as: (a) A bud, in the size and appearance of a reddish-brown cabbage; (b) In the opening phase; (c) In full bloom; and (d) In the decaying phase. 
analysis. Some standard geological equipments such as GPS, compass, hammer etc were brought and used during the field work. The methods used for this study were generally divided into two, i.e. desk study and field study. Desk study required efforts to perform literature study about the topic and the study area. Meanwhile, field study was conducted through field investigations in some locations in the study area (Appendix A). The investigation was part of a scientific expedition in Lojing Highlands organized by Faculty of Agro-based Industry and Faculty of Earth Sciences, Universiti Malaysia Kelantan in January 2014. Geological and geomorphological mapping, rock and water sampling, some measurements, and photograph shoot were conducted during the expedition.

\section{Geomorphology of Study Area}

The geomorphology of study area is related to the geomorphology development of Peninsular Malaysia. Although the Peninsula is considered to have been relatively stable tectonically, it has still been influenced by regional events of Sundaland. Its present-day landforms thus result in part from its prolonged sub-aerial exposure throughout the Tertiary period, with predominance of weathering and erosion. The study area is situated in Lojing Highlands of southern Kelantan, which is a part of the Main Range (Figure 3), the "backbone" of Peninsular Malaysia and the most prominent mountain range in the Peninsula. This mountain range extends from southern Thailand in the north to Negeri Sembilan in the south, with the elevations rarely less than $910 \mathrm{~m}$ and peaks of over $2100 \mathrm{~m}$ [4].

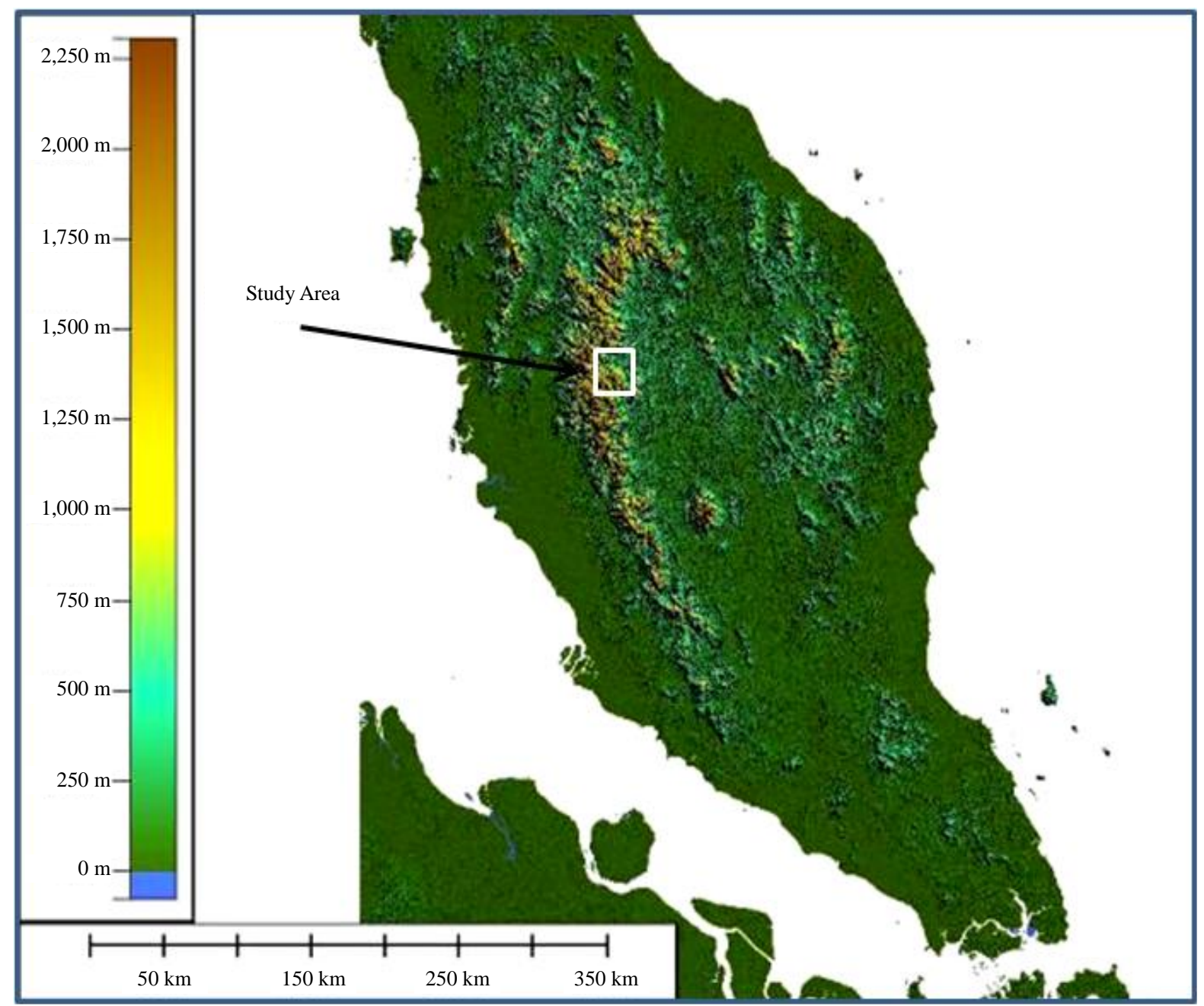

Figure 3. Digital Elevation Model (DEM) Map of Peninsular Malaysia shows the physiography of the Peninsular. The study area (the area in the white box) is located in the foot of the Main Range (or the Titiwangsa Range). 
According to [4], there are five broad topographic units that can be distinguished based on differences in mean elevations: 1) Low lying (<15 m above sea level); 2) Rolling (16 - $30 \mathrm{~m}$ ); 3) Undulating (31 - $75 \mathrm{~m}) ; 4$ ) Hilly (76 - $300 \mathrm{~m}$ ); and 5) Mountainous (>301 m). Meanwhile, [5] divided the landscape in the state of Kelantan into four types, they are: 1) Mountainous areas; 2) Hilly areas; 3) Plain areas; and 4) Coastal areas. The Lojing highlands itself is dominated by the topography of mountainous areas (Figure 4). Some features in the mountainous area are mountain ridges and mountain valleys (Figure 5).

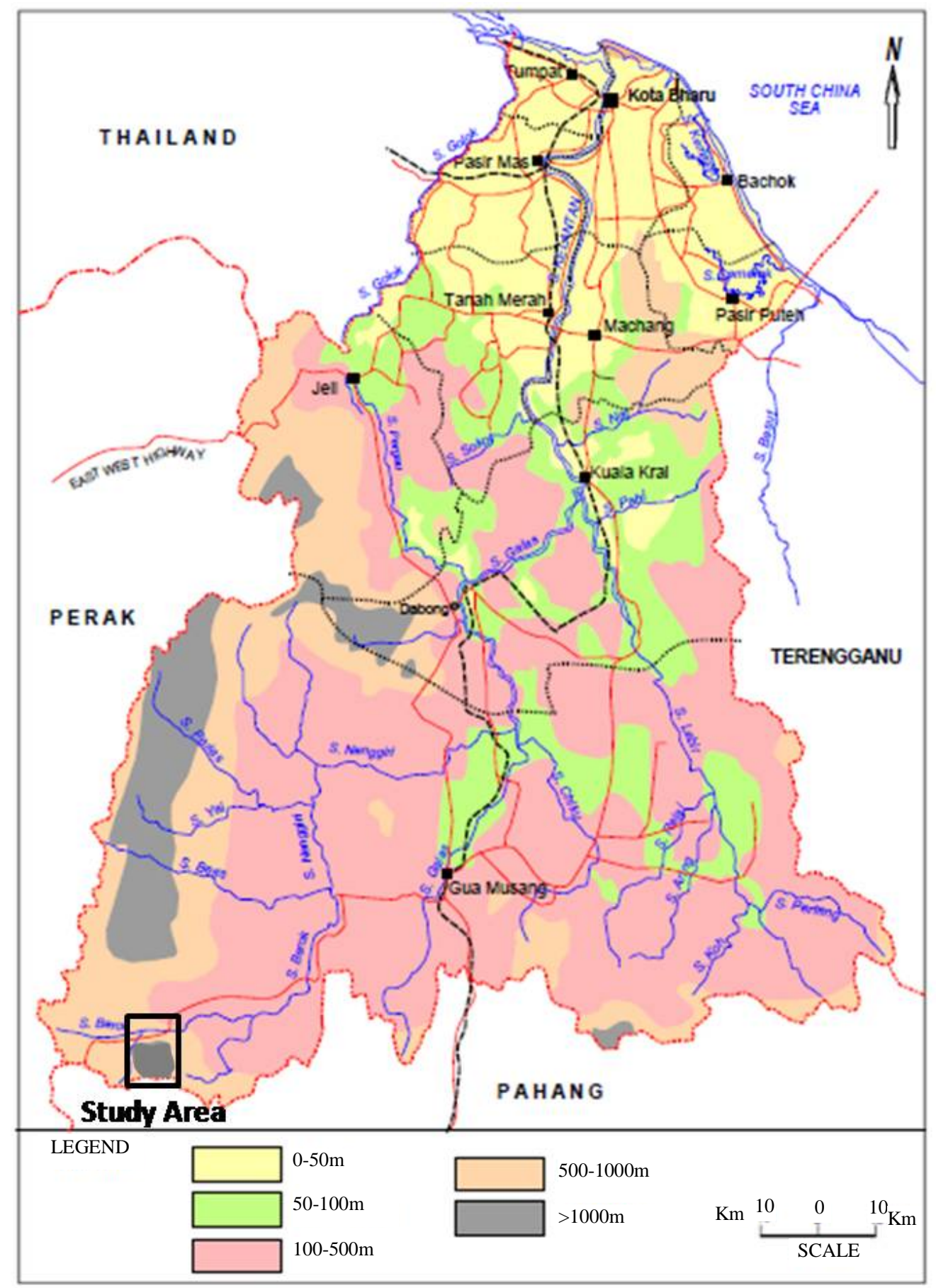

Figure 4. General topography of Kelantan (after [8]). The Lojing highlands itself is dominated by the topography of mountainous areas. 
Mountains alternating with valleys dominate the topography of the study area. The highest point of the study area is nearly $2000 \mathrm{~m}$ which is in the southeast of the area, near the Kelantan-Pahang border, meanwhile the lowest one is $600 \mathrm{~m}$ in the north. The drainage pattern of the area is subdendritic and angulate (Figure 6). Subdendritic pattern (a modified pattern of dendritic type) is presumably controlled by secondary regional controls, such as structural. Meanwhile, angulate (a modified of rectangular) is characterized by numerous acute-angle bends and barbed tributaries which are controlled by joints and/or faults [6] [7]. From these drainage patterns, it can be interpreted that generally this area has been affected by the structural controls such as joints and/or faults. Certain lineament directions can be seen in the study area. For instance, the study area is mostly along the Sungai Denkong that is at least $7 \mathrm{~km}$ long with a bearing around $\mathrm{N} 150^{\circ} \mathrm{E}$. The main factor controlling the drainage basin of Sungai Dengkong is the approximately NNW-SSE - trending mountain range. This river follows almost parallel to the mountain range. Tributaries of this river in general flow relatively to the east or the west.

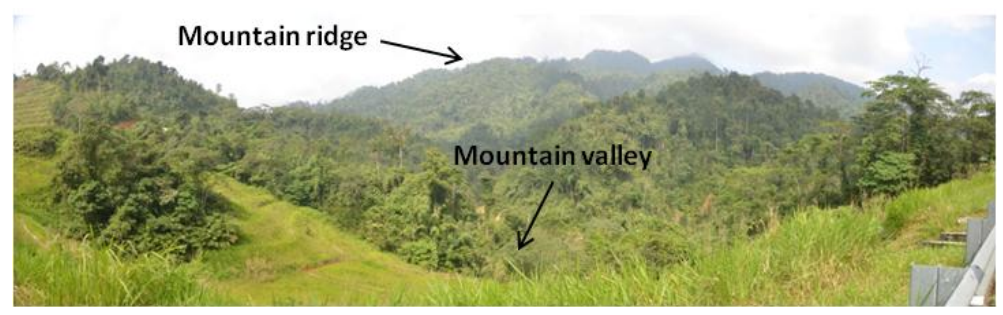

Figure 5. Topography of the study area is dominated among others by mountain ridges and mountain valleys.
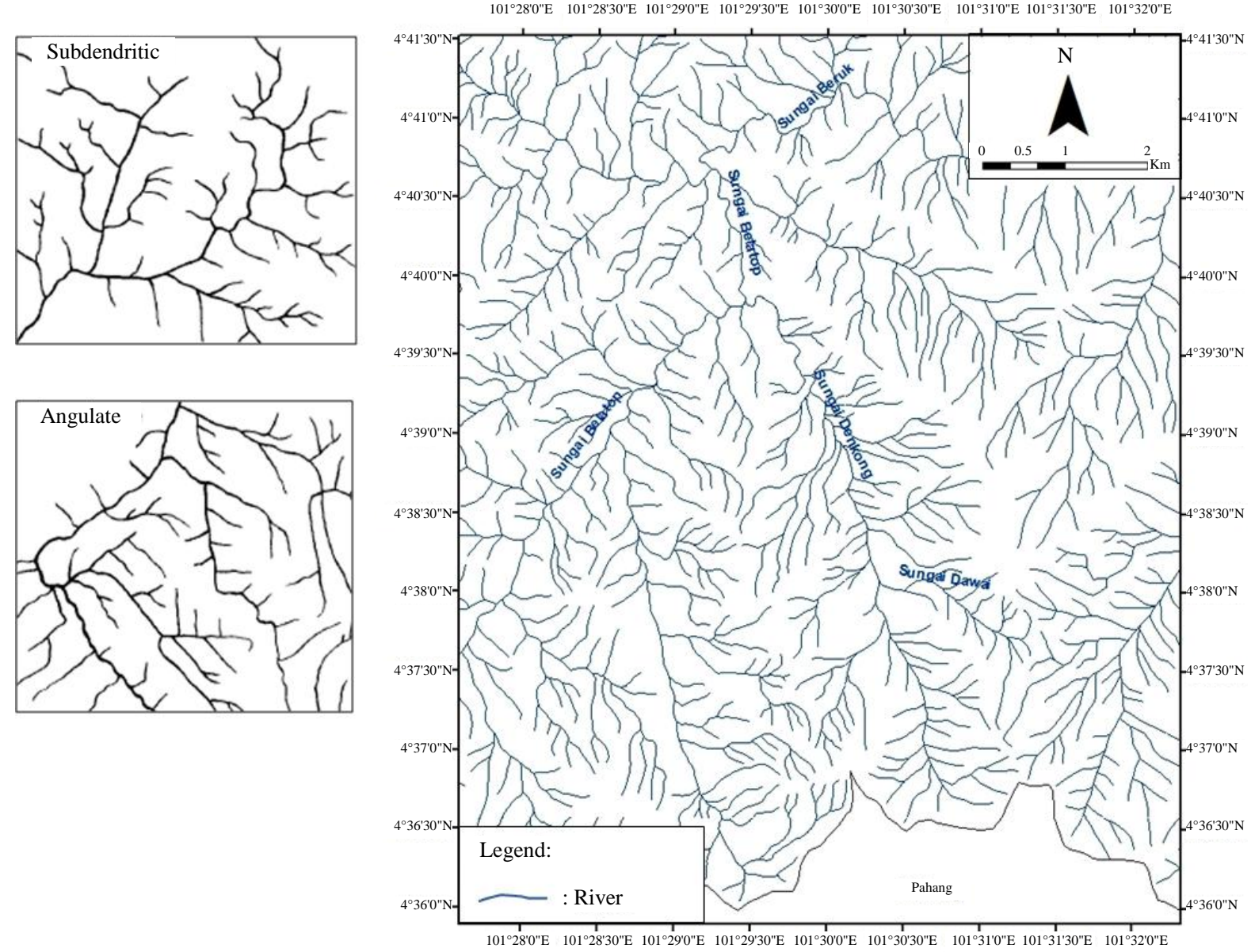

Figure 6. Drainage pattern of the study area is subdendritic and angulate. 
Highland areas in Peninsular Malaysia are formed by a long erosional history through successive uplifts during Cenozoic. This morphology is largely controlled by rock type and structure. The topography is characterized by steep valley walls, numerous waterfalls and rapids, and small remnant upland plateau now providing hill resort like the Cameron Highlands. These features indicate a youthful stage of erosion [9]. In this stage, after uplift, a youthful landscape is characterised by incising V-shaped (steep-sided) valleys because of the rapid deepening of the channels. The rivers flow along an uneven surface and confined valleys. There is intensive and rapid vertical erosion and the gradients are steep (Figure 7).
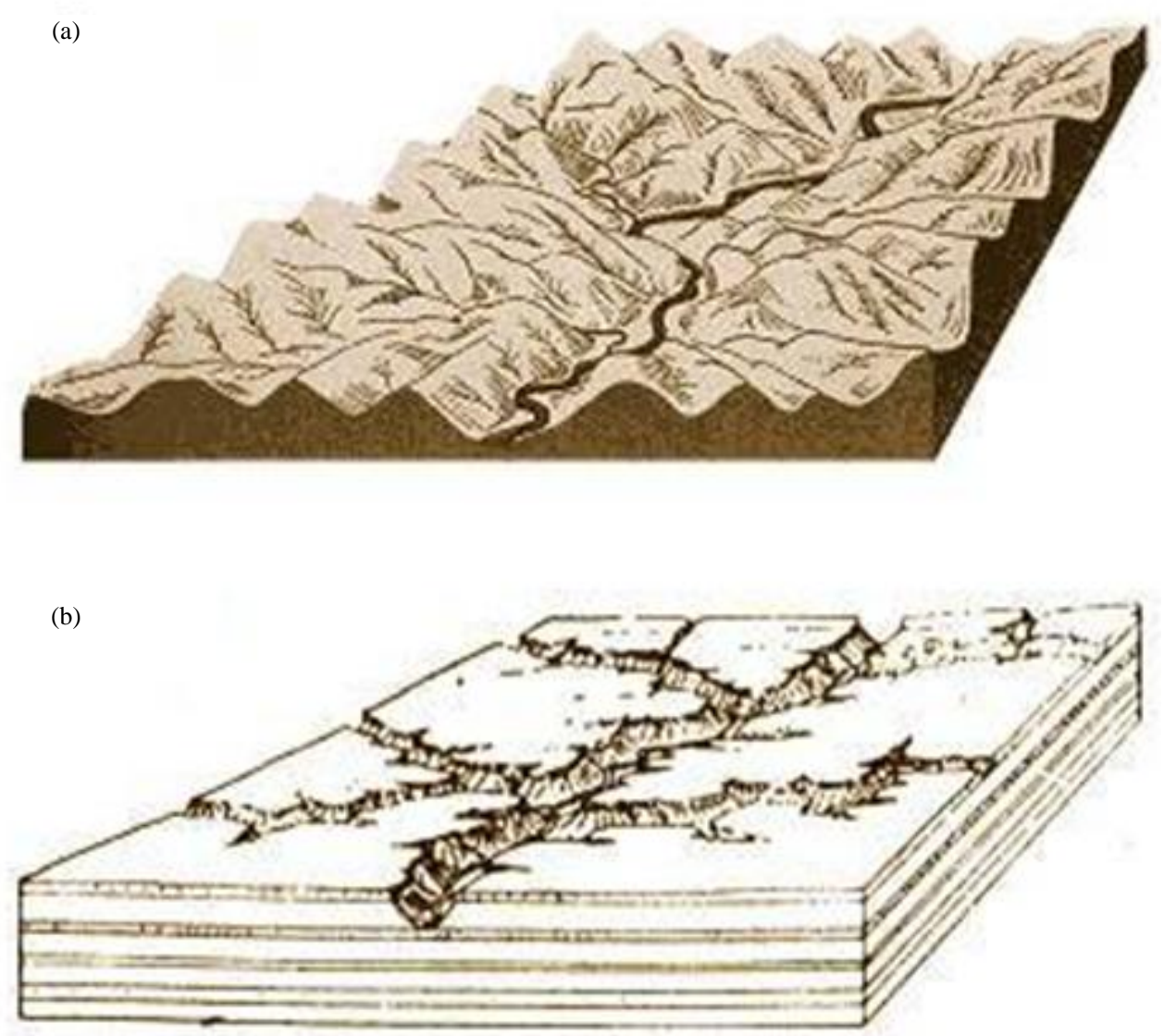

(c)

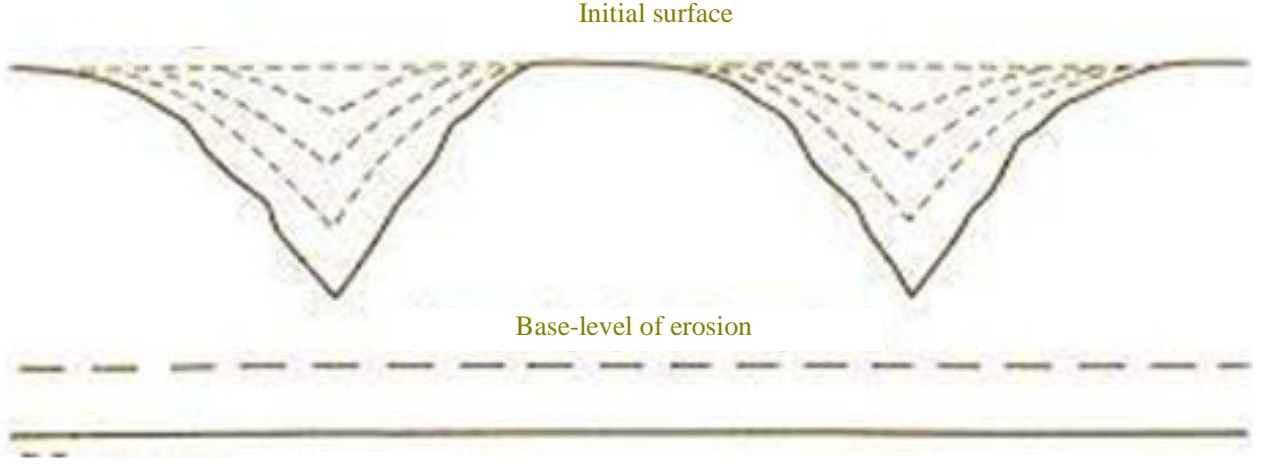

Figure 7. Model of young stage of Davisian cycle of landscape erosion in the study area (after [10]). Rivers in this stage have V-shaped (steep-sided) and confined valleys. 
Some fluvial landforms or geomorphic units occur in the study area, such as waterfalls, cascades, rapids, runs, pools, potholes, lateral bars, and point bars (Figure 8). Waterfalls are usually caused by the rivers encountering some locally and highly resistant rocks whilst deepening their valleys. Waterfalls are characterised by falling flow over bedrock that have a near-vertical drop greater that $1 \mathrm{~m}$. Waterfalls vary considerably in height, form and volume of water. Some of them are small and narrow waterfall and some others are large, even exceptionally large falls occur in some parts in the mountainous areas. Cascades occur on steep slopes and comprise longitudinally and laterally disorganised bed materials, typically cobbles and boulders. A stair-like morphology may develop in settings where the materials are better organised. Rapids are formed by arrangements of boulders in irregular transverse ribs that partially or fully span the channel in bedrock-confined settings during high energy events. In addition, rapids are also caused in many cases by the recession of the waterfall, whilst others occur where streams are eroding rocks of unequal hardness. Runs (or glides) are generally uniform and relatively featureless bed, comprising bedrock or coarse clasts (cobble or gravel). Runs are typically generated under plane-bed conditions with smooth flow. Pools are deeper and confined areas with tranquil flow within high energy settings, usually associated with irregular spaced bedrock outcrops and woods. Pools may accumulate finer grained materials and they are flushed and possibly scoured. Potholes are spherical/circular features sculpted in bedrock by hydraulic and abrasive action of water (erosion during turbulent flow). The effectiveness of this process is determined by the volume and hardness of particles that are trapped in the potholes. Abrasion is induced by these particles, which deepen and widen the potholes. Lateral bars (alternate or side bars) are elongate features attached to banks along relatively straight channels. These bars form by lateral (or oblique) accretion processes, with some suspended-load materials atop (typically fining-upward depositional sequence). Point bars typically have an arcute shape that reflects the radius of curvature of the bend within which they form. These bars develop along the convex banks of meander bends and follow the alignment of the bend. The bar surface is typically inclined towards the channel [4] [7].

\section{Lithology of Study Area}

[11] explained that the state of Kelantan has a wide variety of rocks, including igneous, sedimentary and metamorphic rocks. The rocks in Kelantan are distributed in a north-south trend. For igneous rocks in Kelantan, they
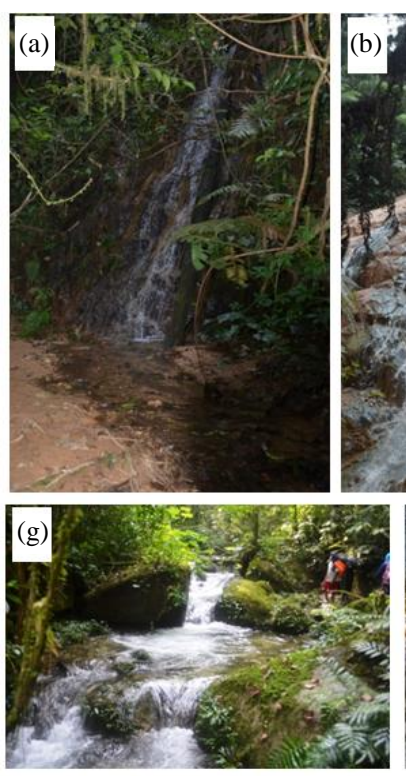
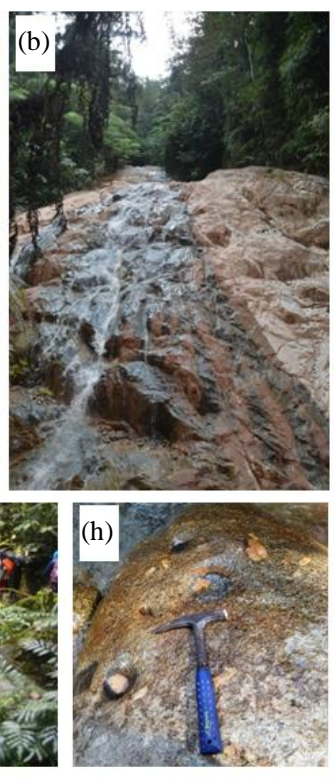
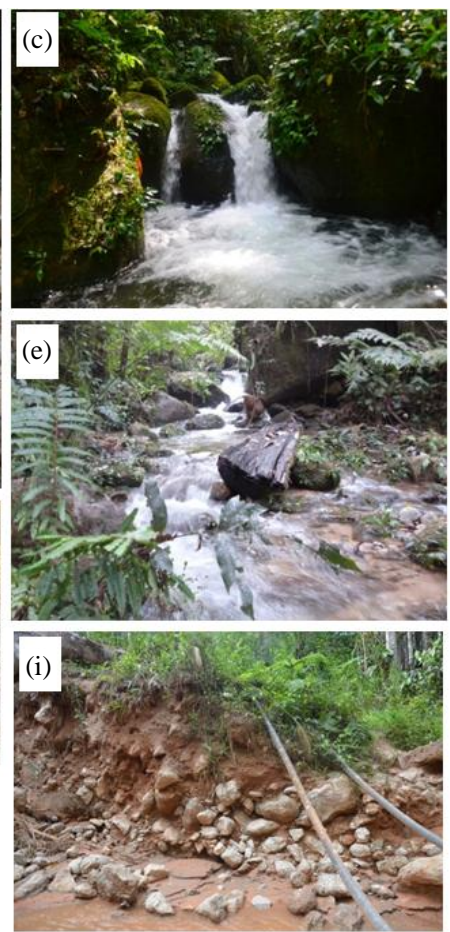
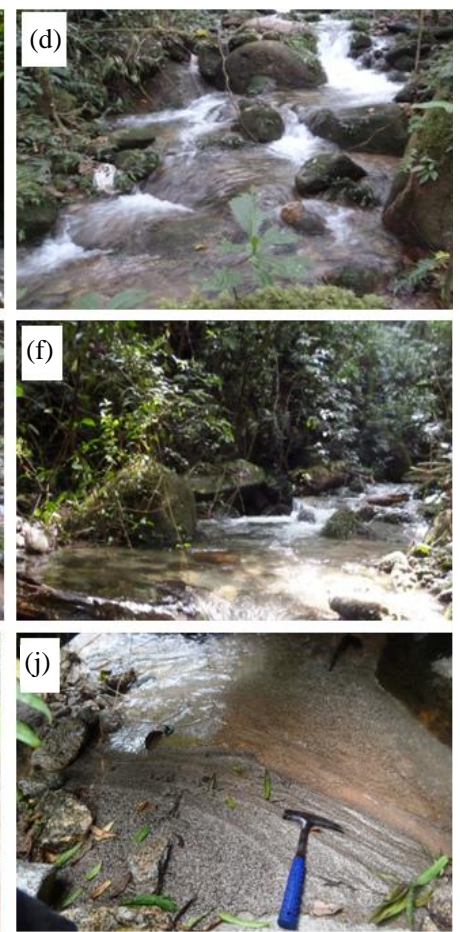

Figure 8. Some fluvial landforms occur in the study area, such as (a), (b), (c) Waterfalls with different sizes, (d) Cascade, (e) Rapids, (f) Run, (g) Pool, (h) Potholes, only a few and small size, (i) Lateral bar, and (j) Point bar. 
are distributed in the west and east borders of the state (the Main Range granite and the Boundary Range granite) and also occur in the centre of the state (Figure 9).

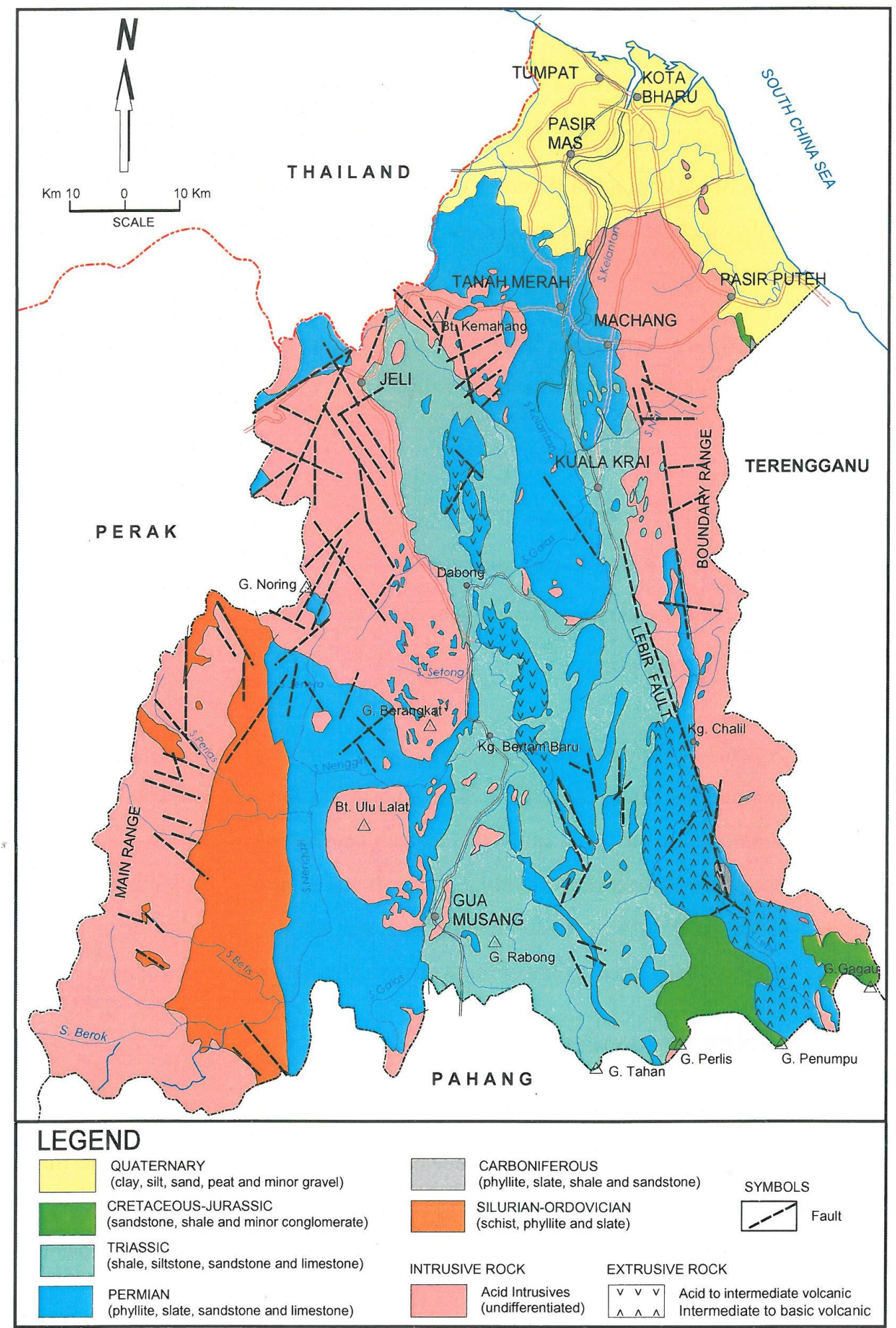

Figure 9. General geology of Kelantan (after [8]). This geological map shows the distribution of rocks in the state. From the map, it is shown that the study area is composed of intrusive rock i.e. granitic rocks. 
The geology of Kelantan can be broadly classified into four rock types, they are: 1) Unconsolidated sediments; 2) Extrusive rocks (volcanic rocks); 3) Sedimentary/metasedimentary rocks; and 4) Granitic rocks. For granitic rocks in Kelantan, they can be divided into two main bodies: the granite bodies within the Main Range and the Boundary Range. The Main Range granite is generally of a Middle Triassic age, between 200 and 230 m.y. [8].

As mentioned before, the study area is situated in Lojing Highlands, which is a part of the Main Range. This range consists mostly of granite with several enclaves of metasedimentary rocks [4]. The Main Range granite in Kelantan located roughly in the west of the state stretching along western Kelantan up to the state boundary of Perak and Pahang, and international boundary of Thailand. According to [12], the main rock type of the Main Range Granite Province is a coarse to very coarse grained megacrystic biotite granite. Large K-feldspar phenocrysts up to $7 \mathrm{~cm}$ long are common and often show a distinctly megacrystic appearance in hand specimen.

Granite outcrops in the study area can be found in large and very large granite bodies and boulders mainly along the rivers. There is no sedimentary and metamorphic rocks found in the study area. Detailed descriptions of rocks in the study area were conducted to some outcrops and hand specimens. Some fresh outcrops in the study area show that the granitic rocks are mostly granite porphyry or porphyritic granite. The rock is light gray, usually weathered to dark gray, and typically coarsed-grained, containing large phenocrysts of white potassium feldspar up to 7 - $8 \mathrm{~cm}$ long. Coarsed-grained groundmass consists of white plagioclase, quartz, and black biotite. Some granites contain xenoliths (size: $>10 \mathrm{~cm}$ ) which are rock fragmens or inclusions which enveloped in a larger rock body usually igneous rocks (Figure 10).

Other than granitic rocks, the study area is also covered by the Quaternary deposits which are alluvium deposits or unconsolidated sediments. The sediments overlie the granitic bedrock and were deposited mainly along the river. The sediments have been transported and deposited by the river flow to form some deposits such as the river banks and sand bars (Figure 11).

\section{Structural Features}

The main force acting on the land mass of Peninsular Malaysia was compressional and its effects are principally faulting and folding in the scale of regional and local. Localised structures include folding, faulting, and jointing in the sedimentary rocks, and faulting and jointing in the granitic rocks. The dominant structural grain is along a $\mathrm{N}-\mathrm{S}$ to NW-SE direction resulting from past orogenies [8].

Geological structures that are commonly found in the study area are joints and brecciation. Joints are fractures in rocks, with no displacement has occurred. Joints can be systematic or non-systematic, and usually occur as fractures which intersect at angles ranging from $45^{\circ}$ to $90^{\circ}$. In the study area, joints divide the rock body into large, roughly angular blocks, which is called as brecciation (Figure 12). According to [13], joints result from strain that occurs when the rocks are uplifted, tilted, folded, or fractured by tectonic forces. [8] stated that joints represent discontinuities in the rock mass. Close spacing of these discontinuities would weaken the rock mass and make it more susceptible to weathering and erosion.
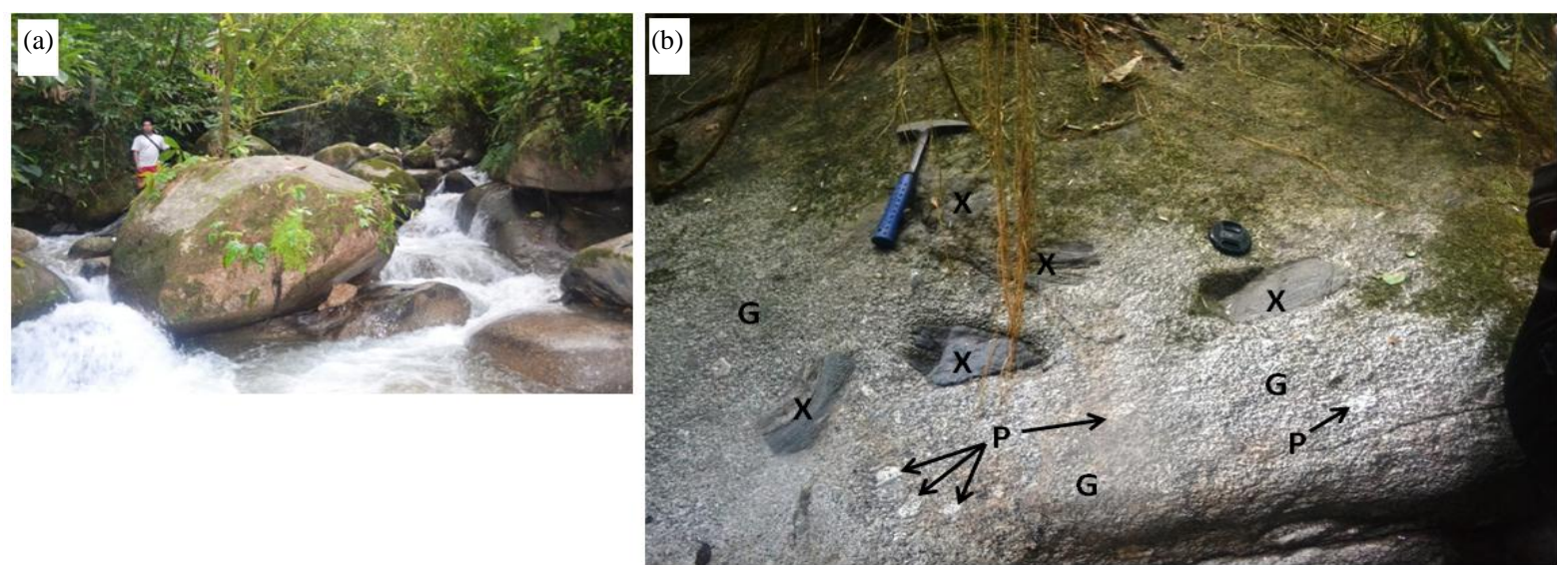

Figure 10. Some granitic outcrops in the study area. (a) Granitic boulders in Sungai Denkong; (b) One of fresh granite outcrops shows the components of the rocks, they are phenocrysts (indicated by $\mathbf{P}$ ), groundmass (G) and xenoliths (X). 

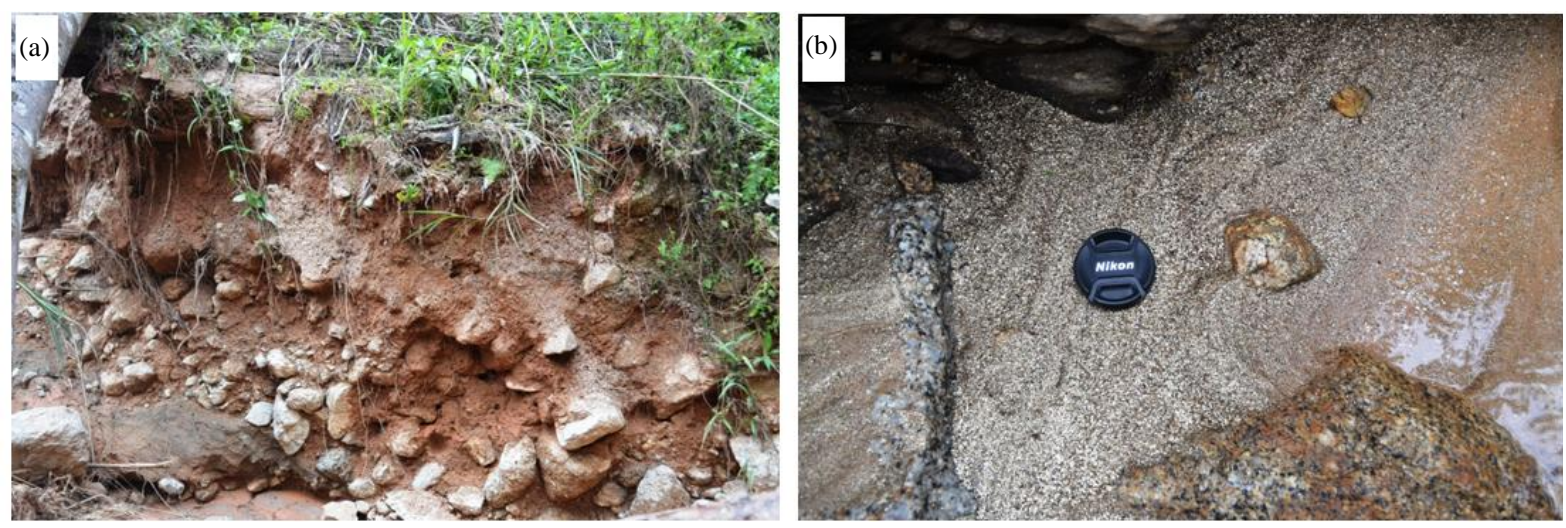

Figure 11. Some outcrops of the Quaternary deposits in the study area. (a) Lateral bar in the river bank of Sungai Bajis in the study area consists of clay- to gravel-sized unconsolidated sediment with fining-upward sequence. (b) A fine-grained point bar consists mostly of pyritic sands.

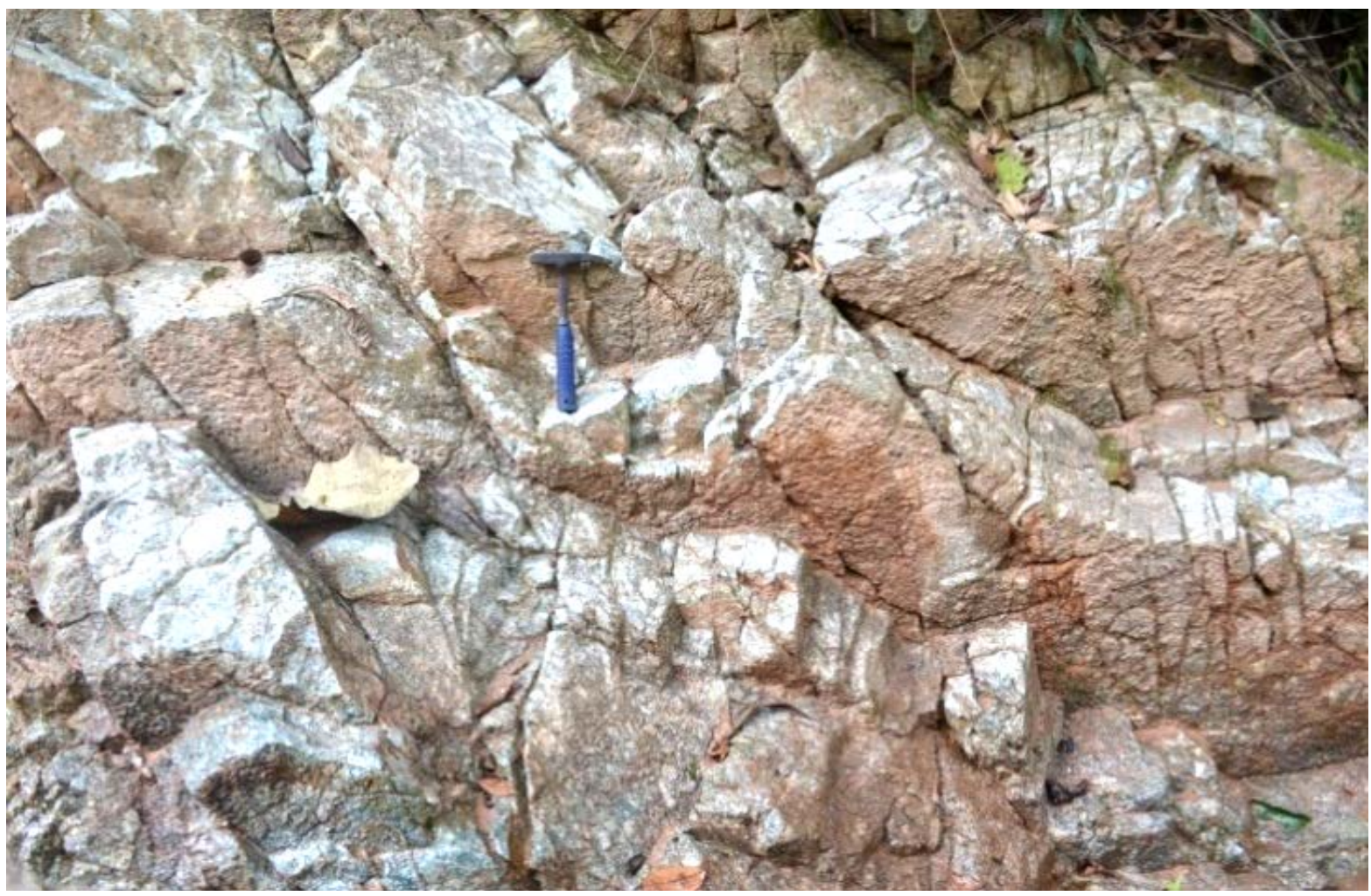

Figure 12. Joints cut the granite body in the study area resulting roughly angular fragments ("brecciation”).

For the sedimentary structure in the study area, some parts of modern sediments in the rivers exhibit ripple mark structures (Figure 13). This structure is a small wave structure (with nearly parallel ridges and troughs) that is formed on a surface of sand and mud by moving water over it [13] [14]. In the study area, the river currents have formed interesting patterns of small ripple marks in flat sandy bed by ongoing geological process. Based on the observation, there are two types of ripple marks can be found in the study area, they are symmetric and asymmetric ripple marks. The geometry of ripple marks depends on the dominant current direction. The symmetric ripples are created by a two-way current and have symmetrical profile. The asymmetric ripples form in response to water currents flowing in one direction and have asymmetric profile. In asymmetric ripples, one side of the ripple has a shallow, gentle, and longer, while the other is steep and abrupt. The longer side always faces the upstream direction. 


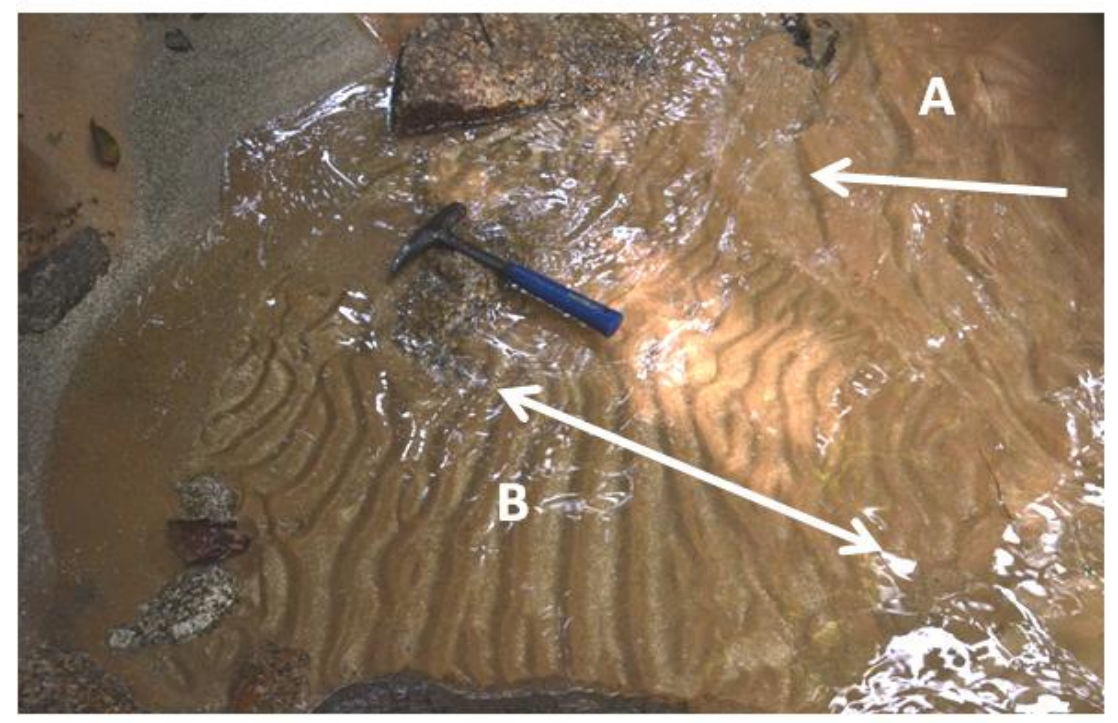

(a)

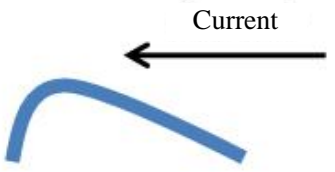

Asymmetric ripple mark

(b)

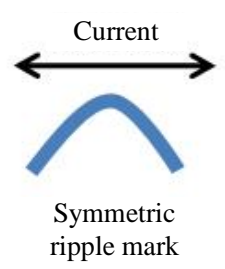

Figure 13. Two types of ripple marks produced on a streambed in the study area indicating the current action of water: (A) Asymmetric ripple mark, and (B) Symmetric ripple mark. The arrows show the current directions.

\section{Geohazard Potentials}

The deforestation in the study area has significant effects on its environment. One of the effects is the potential geological hazard i.e. landslides. According to [15], landslides occur on slopes in a variety of geological materials and develop through a variety of mechanisms and causes. Some parameters are used to classify the landslides, such as material, velocity (rate), scale of the event, displacement (distance), as well as mechanism of movement. The most obvious difference between various kinds of landslide is the nature of participating material. Some slides are entirely composed of rock material, others of soil only, and a few are mixed materials (such as rock and soil). For the velocity of the event, in general terms, rapid landslides occur in seconds to minutes; intermediate rates of movement may be scaled in minutes to hours; and slow landslides develop and move in periods ranging from days to years. The scale of the event and displacement can be measured in the field using units such as meters and kilometers. There are several types of landslides which imply the mechanisms of movement, such as fall, slide, and flow.

There are several landslides occur in the study area recently (Table 1, Figure 14). Although they are small landslides (only a few meters in dimension and displacement), but they still can become a thread and an inconvenience to the area and visitors. Some landslides in the study area are entirely composed of soil only and some others are mixtures of rock and soil. The velocity of the event is difficult to decide since we have just observed after the events. These landslides occur in unstable hill slopes in the study area. The type of movement depends on the character of the material taking part in the movement and the topography (plane or surface of movement). Almost all movements are slides, where we still can observe the sliding surfaces and the sliding materials (mostly soil). For brittle rocks in the steep slopes, the consequence of rock failure will be a fall rather than a slide. So, the mass of rocks, even if they are part of the slide, may fall freely under gravity.

\section{Water Quality Analysis}

The deforestation in the study area can have also significant effect on the water quality. The water quality analysis was conducted to examine the physico-chemical parameters of the stream water in the study area. Three water sampling points were chosen, they are point 1 in Sungai Denkong which flows the clean water, point 2 in Sungai Bajis (a tributary of S. Denkong) which flows the murky and brown water, and point 3 in meeting point between S. Denkong and S. Bajis where the clean water combined with the murky water. Some physical parameters were used in this study such as $p H$, temperature, total dissolved solid (TDS), suspended solid (SS), salinity, and turbidity. Chemical parameters such as conductivity, dissolved oxygen (DO), biochemical oxygen demand $(B O D)$ as well as chemical oxygen demand $(C O D)$ were also used. 
Table 1. Classification of some landslides in the study area.

\begin{tabular}{|c|c|c|c|c|c|c|}
\hline No. & Code of Landslide & Coordinate/Location & Material & Scale (height $\times$ width) & Displacement & Mechanism \\
\hline 1 & LS-1 (Figure 14(a)) & $\begin{array}{l}101^{\circ} 29^{\prime} 39.5^{\prime \prime} \\
04^{\circ} 39^{\prime} 13.6^{\prime \prime}\end{array}$ & Soil & $5 \mathrm{~m} \times 5 \mathrm{~m}$ & A few meters & Slide \\
\hline 2 & LS-2 (Figure 14(b)) & $\begin{array}{c}101^{\circ} 30^{\prime} 13.0^{\prime \prime} \\
04^{\circ} 38^{\prime} 13.1^{\prime \prime}\end{array}$ & Soil & $7 \mathrm{~m} \times 5 \mathrm{~m}$ & A few meters & Slide \\
\hline 3 & LS-3 (Figure 14(c)) & $\begin{array}{c}101^{\circ} 29^{\prime} 53.2^{\prime \prime} \\
04^{\circ} 38^{\prime} 53.1^{\prime \prime}\end{array}$ & Soil + Rock & $3 \mathrm{~m} \times 3 \mathrm{~m}$ & A few meters & Slide + Rockfall \\
\hline 4 & LS-4 (Figure 14(d)) & $\begin{array}{c}101^{\circ} 30^{\prime} 15.6^{\prime \prime} \\
04^{\circ} 38^{\prime} 18.5^{\prime \prime}\end{array}$ & Soil + Rock & $4 \mathrm{~m} \times 3 \mathrm{~m}$ & A few meters & Slide + Rockfall \\
\hline
\end{tabular}
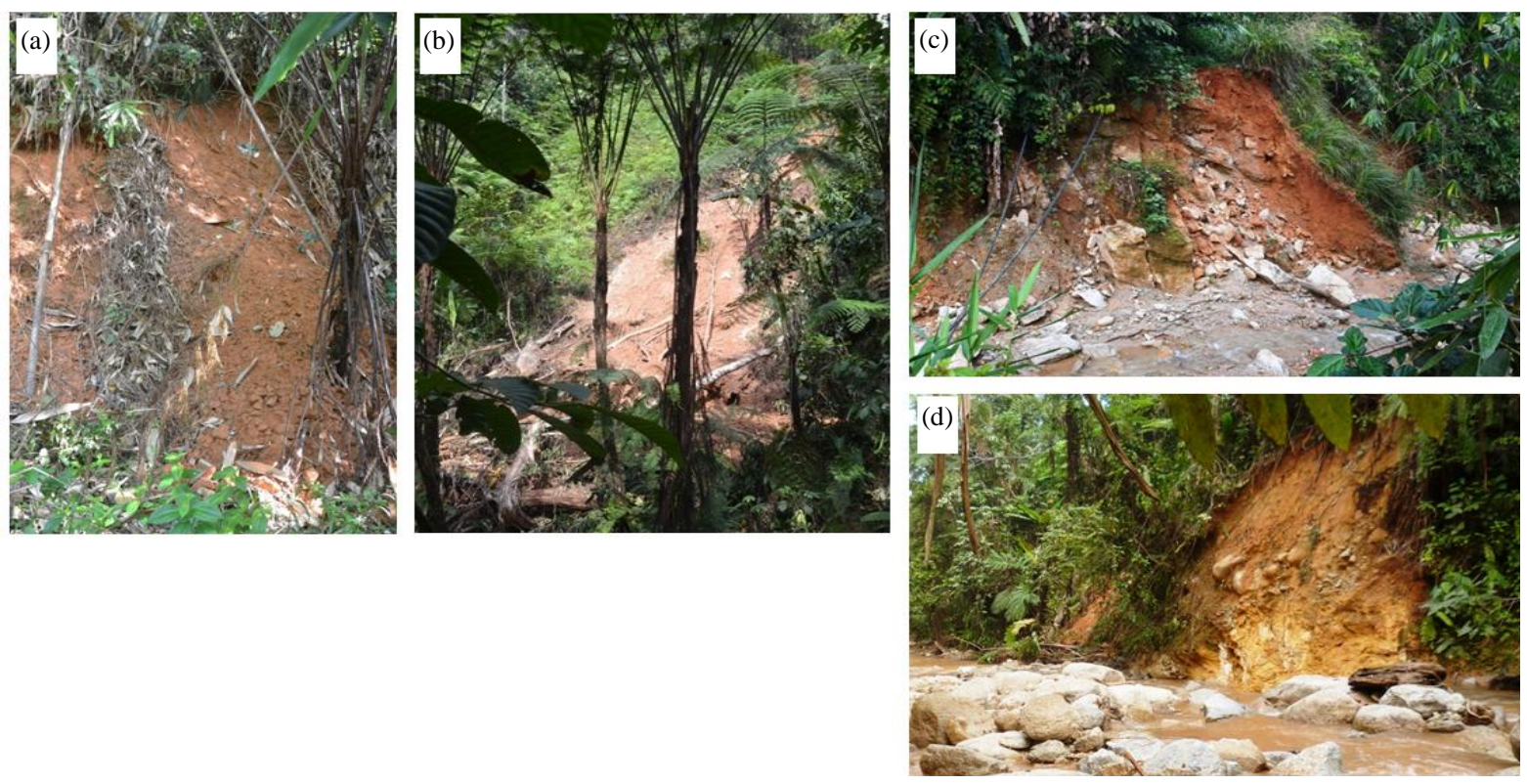

Figure 14. Some landslides in the study area.

The in-situ measurement was done to measure some physical parameters, they are $\mathrm{pH}$, temperature, TDS, and salinity (by using YSI 556 Multiparameter) and turbidity (by using Turbidity Meter). Some chemical parameters i.e. conductivity and DO were also taken using in-situ measurement (by using YSI 556 Multiparameter). For the in-situ measurement, the equipments were placed in the middle of the stream and allowed to stabilize before readings were taken. Meanwhile, ex-situ measurement (in the lab) was conducted to measure SS (by using Spectrophotometer DR 2800 Hach), BOD (by using LBOD101 Hach), and COD (by using DRB 200 Digital Reactor Hach and Spectrophotometer DR 2800 Hach). Furthermore, the results gained from this analysis were compared to Interim National Water Quality Standard (INWQS) for Malaysia [16] (Appendix B).

The physico-chemical water parameters for streams surveyed are summarised in Table 2. According to in-situ measurements, $\mathrm{pH}$ of streams (freshwaters) ranges from 6.43 - 6.63. The water temperature is generally cold water, ranging from $18.07^{\circ} \mathrm{C}-18.99^{\circ} \mathrm{C}$. The concentrations of total dissolved solids (TDS) are very low, in the range of $0.004-0.009 \mathrm{mg} / \mathrm{l}$. The salinity of streams was not significant, ranging only $0-0.01$ ppt. The conductivity values for these three points are very low and ranged only between $0.005-0.012 \mu \mathrm{S} / \mathrm{cm}$. The concentrations of dissolved oxygen (DO) range 2.07 - $2.38 \mathrm{mg} / \mathrm{l}$.

The turbidity is various significantly between point to point. Point 1 (upstream of S. Denkong) has low turbidity i.e. 3.99 NTU, with the crystal clear water. Point 2 (S. Bajis) is a contaminated water body which receives large amount of eroded soils has very high turbidity i.e. > 1000 NTU. Meanwhile, the turbidity at point 3 (meeting point between S. Denkong and S. Bajis) is moderate, which is 56.8 NTU due to the mixture between the clear water of S. Denkong and the polluted water of S. Bajis. The pollution of S. Bajis is assumed as the effect of soil erosion due to deforestation in the upstream area. The suspended solid is proporsional to turbidity. Point 1, with low turbidity, has also low SS, i.e. $4 \mathrm{mg} / \mathrm{l}$. Point 2, with very high turbidity, has also very high SS, i.e. $911 \mathrm{mg} / \mathrm{l}$. The SS in point 3 is relatively moderate i.e. $47 \mathrm{mg} / \mathrm{l}$. The values of BOD range from 8.92 - 9.14 
Table 2. Water quality analysis of some water sampling points in the study area.

\begin{tabular}{|c|c|c|c|c|c|c|c|c|c|c|c|c|}
\hline \multirow{2}{*}{$\begin{array}{l}\text { Sampling } \\
\text { Point }\end{array}$} & \multirow{2}{*}{$\begin{array}{l}\text { Coordinate/ } \\
\text { Location }\end{array}$} & \multirow{2}{*}{$\mathrm{pH}^{7}$} & \multirow{2}{*}{$\begin{array}{l}\text { Temp. } \\
\left({ }^{\circ} \mathrm{C}\right)\end{array}$} & \multirow{2}{*}{$\begin{array}{l}\text { TDS } \\
(\mathrm{mg} / \mathrm{l})\end{array}$} & \multirow{2}{*}{$\begin{array}{l}\text { Salinity } \\
\text { (ppt) }\end{array}$} & \multirow{2}{*}{$\begin{array}{l}\text { Conductivity } \\
\qquad(\mu \mathrm{S} / \mathrm{cm})\end{array}$} & \multicolumn{2}{|l|}{ DO } & \multirow{2}{*}{$\begin{array}{l}\text { Turbidity } \\
\text { (NTU) }\end{array}$} & \multirow{2}{*}{$\begin{array}{c}\mathrm{SS} \\
(\mathrm{mg} / \mathrm{l})\end{array}$} & \multirow{2}{*}{$\begin{array}{l}\text { BOD } \\
(\mathrm{mg} / \mathrm{l})\end{array}$} & \multirow{2}{*}{ COD (mg/l) } \\
\hline & & & & & & & (\% saturation) & $(\mathrm{mg} / \mathrm{l})$ & & & & \\
\hline $\begin{array}{l}\text { Point } 1 \\
\text { (S. Denkong) }\end{array}$ & $\begin{array}{c}101^{\circ} 30^{\prime} 16.06^{\prime \prime} \mathrm{E} \\
04^{\circ} 38^{\prime} 17.44^{\prime \prime N}\end{array}$ & 6.43 & 18.07 & 0.009 & 0.00 & 0.012 & 25.1 & 2.38 & 3.99 & 4 & 9.00 & 40 \\
\hline $\begin{array}{l}\text { Point } 2 \\
\text { (S. Bajis) }\end{array}$ & $\begin{array}{c}101^{\circ} 30^{\prime} 14.34^{\prime \prime} \mathrm{E} \\
04^{\circ} 38^{\prime} 17.65^{\prime \prime N}\end{array}$ & 6.63 & 18.99 & 0.004 & 0.00 & 0.005 & 22.3 & 2.07 & $>1000$ & 911 & 8.92 & 37 \\
\hline $\begin{array}{l}\text { Point } 3 \text { (Meeting } \\
\text { point between S. } \\
\text { Denkong \& S. } \\
\text { Bajis) }\end{array}$ & $\begin{array}{c}101^{\circ} 30^{\prime} 15.62 " \mathrm{E} \\
04^{\circ} 38^{\prime} 19.80^{\prime \prime} \mathrm{N}\end{array}$ & 6.61 & 18.14 & 0.009 & 0.01 & 0.012 & 21.9 & 2.07 & 56.8 & 47 & 9.14 & 50 \\
\hline
\end{tabular}

$\mathrm{mg} / \mathrm{l}$ and the values of COD are between 37 - $50 \mathrm{mg} / \mathrm{l}$. According to all these parameters, the water quality in the study area is generally Class III. According to INWQS for Malaysia, the Class III water means that this water can be used for water supply with the extensive treatment.

\section{Conclusion}

Even though this area has no special or unique geological features, geological studies are still important to be performed to give detailed and updated geological information. Some geological studies have been conducted in the study area including geomorphology, lithology, structural features, geohazard potentials, and water quality analysis. The study area is famous for Rafflesia and has become the main attraction in Lojing Highlands. This area is also attractive with its mountainous area and some fluvial features, such as waterfalls, cascades, rapids, pools, potholes, and so on. It is monotonously composed of granitic rocks, mostly granite porphyry, and covered by Quaternary deposits. Meanwhile, the geological structure that is commonly found in the study area is joints. The recently active deforestation in the area has given some impacts on the environment, such as landslides and the degradation of water quality. Water quality analysis shows that this area generally has the Class III water (according to INWQS for Malaysia) which means that the water can be used for the water supply (public uses) with the extensive treatment required. This water can also be used for livestock drinking. However, some streams in the study area have crystal clear and uncontaminated water, such as the upstream part of Sungai Denkong and some of its tributaries (such as Sungai Dawai). Some others supply polluted water, such as Sungai Bajis, due to the effective soil erosion. With this condition, it is suggested that this area should be conserved and developed properly. This study also recommends that this area should be supported as a sustainable tourism site in Lojing Highlands.

\section{Acknowledgments}

We would like to thank Faculty of Agro-based Industry and Faculty of Earth Sciences, Universiti Malaysia Kelantan (UMK) Jeli Campus for organizing a scientific expedition to explore some parts in Lojing Highlands. We would also like to appreciate the local community of Temiar for guiding us during conducting the expedition. Thanks are also due to all colleagues and researchers involved in the expedition.

\section{References}

[1] Hamzah, Z., Mohammed, M., Peter, C. and Mansur, M.M. (2010) Spatial Distribution and Conservation of Rafflesia kerrii in Lojing Highlands, Kelantan. In: Omar, I.C. and Hamzah, Z., Eds., Conserving Lojing Highlands for Sustainable Development, Penerbit UMK, 44-54.

[2] Siti Munirah, M.Y. (2012) Rafflesia Blooms in Royal Belum. Conservation Malaysia. A Bulletin Supporting Plant and Animal Conservation in Malaysia.

[3] WHOA! (Wildlife Highlands Ocean Air!) (2014) Lojing Highlands. http://whoaadventures.com/adventure/highlands-and-jungle/lojing-highlands

[4] Raj, J.K. (2009) Geomorphology. In: Hutchison, C.S. and Tan, D.N.K., Eds., Geology of Peninsular Malaysia, Geological Society of Malaysia, Kuala Lumpur, 5-29.

[5] Unjah, T., Komoo, I. and Mohamad, H. (2001) Pengenalpastian Sumber Warisan Geologi di Negeri Kelantan. In: Komoo, I., Tjia, H.D. and Leman, M.S., Eds., Geological Heritage of Malaysia (Geoheritage Mapping and Geosite Cha- 
racterization), LESTARI UMK, Bangi.

[6] Howard, A.D. (1967) Drainage Analysis for Geologic Interpretation: A Summation. AAPG Bulletin, 51, $2246-2259$.

[7] Fryirs, K.A. and Brierley, G.J. (2013) Geomorphic Analysis of River Systems: An Approach to Reading the Landscape. Wiley-Blackwell, Hoboken.

[8] Department of Minerals and Geoscience Malaysia (2003) Quarry Resource Planning for the State of Kelantan. Osborne \& Chappel Sdn. Bhd.

[9] Tjia, H.D. (1973) Geomorphology. In: De Sitter, L.U., Ed., Geology of the Malay Peninsula, John Wiley \& Sons, Inc., Hoboken, 13-24.

[10] Association of Polish Geomorphologists (2009) Stages in the Fluvial Cycle of Erosion. http://www.staff.amu.edu.pl/ sgp/gw/wmd/wmdfig.html

[11] Rahman, C.A. and Mohamed, K.R. (2001) Pemetaan Awalan Sumber Warisan Geologi Negeri Kelantan. In: Komoo, I., Tjia, H.D. and Leman, M.S., Eds., Geological Heritage of Malaysia (Geoheritage Mapping and Geosite Characterization), LESTARI UMK, Bangi.

[12] Ghani, A.A. (2009) Plutonism. In: Hutchison, C.S. and Tan, D.N.K., Eds., Geology of Peninsular Malaysia, Geological Society of Malaysia, Kuala Lumpur, 211-232.

[13] Hamblin, W.K. (1994) Introduction to Physical Geology. Macmillan Publishing Company, London, 400 p.

[14] Thomson, G.R. and Turk, J. (2007) Earth Science and the Environment, 4th Edition, Thomson Brooks/Cole, Belmont, $635 \mathrm{p}$.

[15] Bolt, B.A., Horn, W.L., Macdonald, G.A. and Scott, R.F. (1975) Geological Hazards. Springer-Verlag, Berlin, 328 p. http://dx.doi.org/10.1007/978-3-642-86820-7

[16] Department of Environment (DOE) Malaysia (2011) Malaysia Environmental Quality Report 2011. Ministry of Natural Resources and Environment. 


\section{Appendix A}

Details of Observation Points and Locations in the Study Area

\begin{tabular}{|c|c|c|c|}
\hline Observation Point & Coordinates (E \& N) & Location and Feature & Elevation (m) \\
\hline 1 & $\begin{array}{l}101^{\circ} 29^{\prime} 20.8^{\prime \prime} \\
04^{\circ} 39^{\prime} 43.4^{\prime \prime}\end{array}$ & Starting point of the Rafflesia Trails & 688 \\
\hline 2 & $\begin{array}{l}101^{\circ} 29 ' 39.5^{\prime \prime} \\
04^{\circ} 39^{\prime} 13.6^{\prime \prime}\end{array}$ & A small landslide & 847 \\
\hline 3 & $\begin{array}{l}101^{\circ} 29^{\prime} 53.2^{\prime \prime} \\
04^{\circ} 38^{\prime} 53.1^{\prime \prime}\end{array}$ & A small landslide (slide + rockfall) & 889 \\
\hline 4 & $\begin{array}{l}101^{\circ} 30^{\prime} 16.8^{\prime \prime} \\
04^{\circ} 38^{\prime} 37.7^{\prime \prime}\end{array}$ & A small waterfall $\left(\sim 1^{\circ} \mathrm{m}\right)$ & 951 \\
\hline 5 & $\begin{array}{l}101^{\circ} 30^{\prime} 10.1^{\prime \prime} \\
04^{\circ} 38^{\prime} 21.8^{\prime \prime}\end{array}$ & A Rafflesia kerrii is blooming & 965 \\
\hline 6 & $\begin{array}{l}101^{\circ} 30^{\prime} 15.6^{\prime \prime} \\
04^{\circ} 38^{\prime} 18.5^{\prime \prime}\end{array}$ & $\begin{array}{l}\text { Meeting point between S. Denkong and S. Bajis. } \\
\text { A small landslide (slide + rockfall) }\end{array}$ & 997 \\
\hline 7 & $\begin{array}{l}101^{\circ} 30^{\prime} 12.4^{\prime \prime} \\
04^{\circ} 38^{\prime} 15.9^{\prime \prime}\end{array}$ & A large waterfall (part of S. Bajis, a tributary of S.Denkong) & 992 \\
\hline 8 & $\begin{array}{l}101^{\circ} 30^{\prime} 13.0^{\prime \prime} \\
04^{\circ} 38^{\prime} 13.1^{\prime \prime}\end{array}$ & A small landslide & 1005 \\
\hline 9 & $\begin{array}{l}101^{\circ} 30^{\prime} 20.6^{\prime \prime} \\
04^{\circ} 38^{\prime} 03.5^{\prime \prime}\end{array}$ & Meeting point between S. Denkong and S. Dawai & 941 \\
\hline 10 & $\begin{array}{l}101^{\circ} 30^{\prime} 23.5^{\prime \prime} \\
04^{\circ} 37^{\prime} 57.3^{\prime \prime}\end{array}$ & Base camp & 1040 \\
\hline 11 & $\begin{array}{l}101^{\circ} 30 ' 21.4^{\prime \prime} \\
04^{\circ} 37^{\prime} 50.4^{\prime \prime}\end{array}$ & S. Denkong (towards upstream) & 1047 \\
\hline 12 & $\begin{array}{l}101^{\circ} 30^{\prime} 23.9^{\prime \prime} \\
04^{\circ} 37^{\prime} 46.2^{\prime \prime}\end{array}$ & A small waterfall and cascade (part of S. Denkong) & 1050 \\
\hline
\end{tabular}

\section{Appendix B}

Interim National Water Quality Standard (INWQS) for Malaysia (DOE Malaysia, 2011)

\begin{tabular}{|c|c|c|c|c|c|c|c|}
\hline \multirow{2}{*}{ PARAMETER } & \multirow{2}{*}{ UNIT } & \multicolumn{6}{|c|}{ CLASS } \\
\hline & & $\mathbf{I}$ & IIA & IIB & III & IV & $\mathbf{V}$ \\
\hline Ammonical Nitrogen & mg/l & 0.1 & 0.3 & 0.3 & 0.9 & 2.7 & $>2.7$ \\
\hline Biochemical Oxygen Demand & mg/l & 1 & 3 & 3 & 6 & 12 & $>12$ \\
\hline Chemical Oxygen Demand & mg/l & 10 & 25 & 25 & 50 & 100 & $>100$ \\
\hline Dissolved Oxygen & $\mathrm{mg} / \mathrm{l}$ & 7 & $5-7$ & $5-7$ & $3-5$ & $<3$ & $<1$ \\
\hline pH & - & $6.5-8.5$ & $6-9$ & $6-9$ & $5-9$ & $5-9$ & - \\
\hline Colour & TCU & 15 & 150 & 150 & - & - & - \\
\hline Electrical Conductivity* & $\mu \mathrm{S} / \mathrm{cm}$ & 1000 & 1000 & - & - & 6000 & - \\
\hline Floatables & - & $\mathrm{N}$ & $\mathrm{N}$ & $\mathrm{N}$ & - & - & - \\
\hline Odour & - & $\mathrm{N}$ & $\mathrm{N}$ & $\mathrm{N}$ & - & - & - \\
\hline Salinity & $\%$ & 0.5 & 1 & - & - & 2 & - \\
\hline Taste & - & $\mathrm{N}$ & $\mathrm{N}$ & $\mathrm{N}$ & - & - & - \\
\hline Total Dissolved Solid & mg/l & 500 & 1000 & - & - & 4000 & - \\
\hline Total Suspended Solid & mg/l & 25 & 50 & 50 & 150 & 300 & 300 \\
\hline Temperature & ${ }^{\circ} \mathbf{C}$ & - & Normal $+2^{\circ} \mathrm{C}$ & - & Normal $+2^{\circ} \mathrm{C}$ & - & - \\
\hline Turbidity & NTU & 5 & 50 & 50 & - & - & - \\
\hline Faecal Coliform** & Count/100 ml & 10 & 100 & 400 & $5000(20000)^{a}$ & $5000(20000)^{\mathrm{a}}$ & - \\
\hline Total Coliform & Count $/ \mathbf{1 0 0} \mathrm{ml}$ & 100 & 5000 & 5000 & 50000 & 50000 & $>50000$ \\
\hline
\end{tabular}

Note: N: No visible floatable materials or debris, no objectional odour or no objectional taste; *: Related parameters, only one recommended for use; **: Geometric mean; a: Maximum not to be exceeded. 
Water Classes and Uses (DOE Malaysia, 2011)

CLASS

Conservation of natural environment.

Class I Water Supply I-Practically no treatment necessary.

Fishery I-Very sensitive aquatic species.

Water Supply II—Conventional treatment required.

Class IIA $\quad$ Water Supply II-Conventional treatm

Class IIB Recreational use with body contact.

Class III

Water Supply III—Extensive treatment required.

Fishery III-Common, of economic value and tolerant species; livestock drinking.

Class IV Irrigation

Class V

None of the above.

USES

.


Scientific Research Publishing (SCIRP) is one of the largest Open Access journal publishers. It is currently publishing more than 200 open access, online, peer-reviewed journals covering a wide range of academic disciplines. SCIRP serves the worldwide academic communities and contributes to the progress and application of science with its publication.

Other selected journals from SCIRP are listed as below. Submit your manuscript to us via either submit@scirp.org or Online Submission Portal.
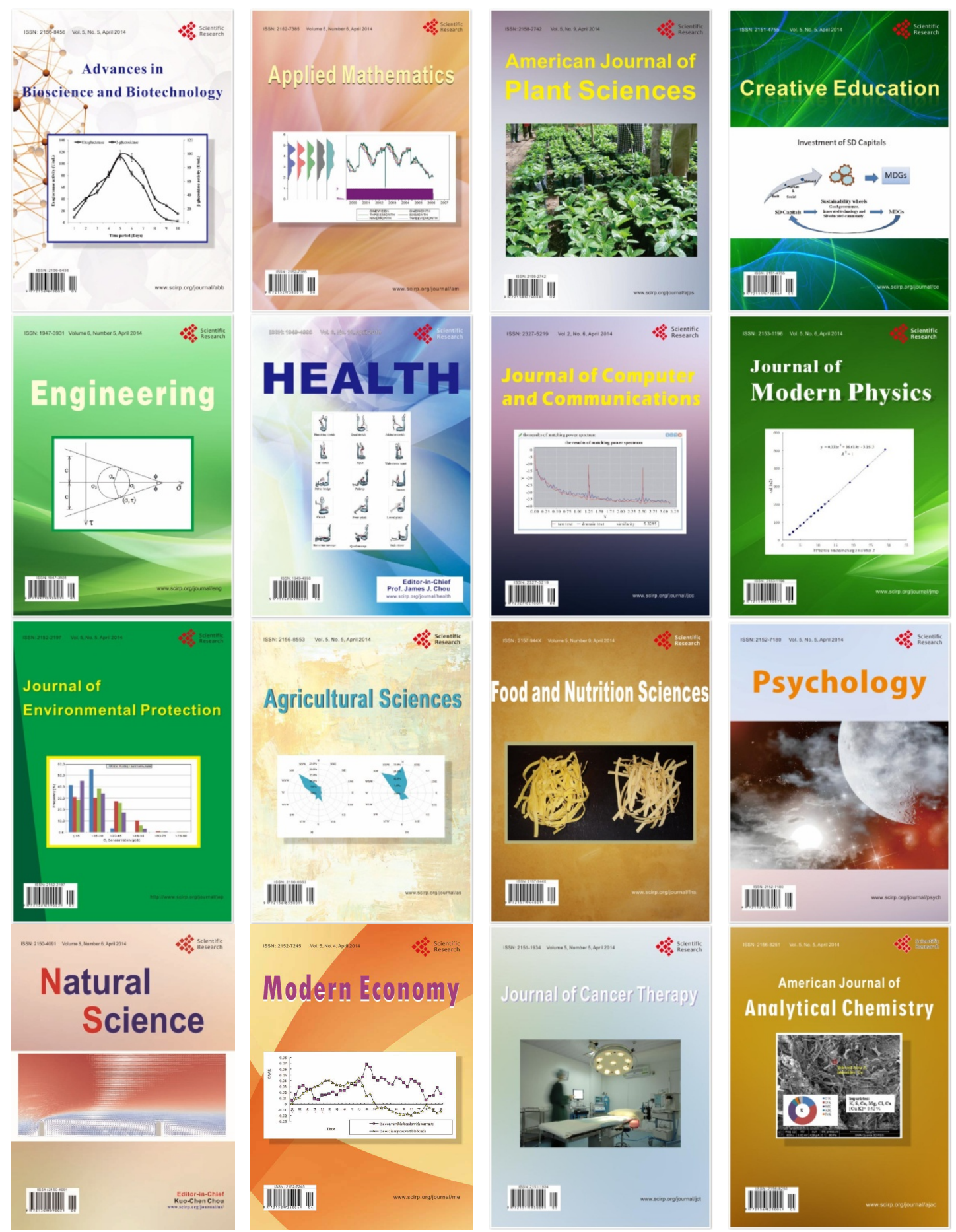